\title{
Hydrographic Training in Belgium
}

Marc DAUWE, Belgium

Antwerp Maritime Academy

Micha LIBERT, Belgium

Antwerp Maritime Academy

Axel ANNAERT, Belgium

Antwerp Maritime Academy

Topic L: the hydrographic profession

\section{INTRODUCTION}

Nautical charts for mariners, tidal predictions and information on changes in navigational areas are indispensable to the global merchant marine, and offshore, dredging and underwater projects. Collecting data on the world's oceans and seas is the responsibility of hydrographers. Their expertise is essential to modern society and economic systems, underlining the importance of quality education in this field.

Recent survey studies in the Netherlands ${ }^{1}$ and Belgium ${ }^{2}$ however, have pointed to a weakness in hydrographic training in both countries, with a shortage of both suitable programmes and institutions offering such training. In Belgium, most hydrographers are engineers who are trained within a company. This implies a potentially unnecessarily long period of training before they are fully employable as hydrographers. ${ }^{3}$

A market study on hydrographic surveyors in Belgium revealed that over 300 hydrographic surveyors are active in Belgium, of whom a large portion are not certified. Moreover, the industry would need another 35 new hydrographic surveyors annually. With this in mind, the present system of companies using in-house training of existing engineers risks inefficiency, as well as missing the benefits of a healthy academy in support of the industry. Investigations on a global scale underline the shortage in hydrographic surveyors even further. ${ }^{4}$

Only few institutes in Europe offer programmes in hydrography, especially in English or the advanced category. In such a globalised set of industries as professional hydrographic expertise is required in, the lack of adequate training in English at the highest level represents a serious weakness. The Antwerp Maritime Academy (HZS) responded to the growing need with postgraduate programmes in hydrography. The institute established the postgraduate programmes Cat. B and Cat. A.

\footnotetext{
${ }^{1}$ Annelies Claeys, "Rapport hydrografieonderzoek" (Ma diss., Ghent University, 2009).

2 Rodrigue Bijlsma, "Hydrografie" (Ba diss., Antwerp Maritime Academy, 2011); Rodrigue Bijlsma, "Hydrografie. Het in kaart brengen van de Belgische hydrografische sector, de Europese IHO gecertificeerde opleidingen en Het Institute For Hydrography" (Ma diss., Antwerp Maritime Academy, 2012).

${ }^{3}$ Bijlsma, "Hydrografie. Het in kaart brengen van ...", p. 83.

${ }^{4}$ Ibid.
} 


\section{METHODS}

\section{History and the establishment of a programme}

Some situations underlined the need for a proper programme in hydrography. The continuous interest in the introductory course in hydrography at the HZS, and the results of the market research, indicating a deficiency in top level professional qualification and certification, revealed a niche for setting up the first full programme of hydrography in Belgium.

The HZS organised a round table discussion concerning the absence of proper education for professional hydrographers. Several higher education institutes, Flanders Hydrographic Services, Flanders Hydraulics and the industry attended the discussion in March 2010. The conclusion of the meeting was clear: there is a need for hydrographic training in Belgium and the new programme should put a strong emphasis on international recognition and accessibility.

During several meetings over the course of two years, continuous deliberation led to the definition of the programmes. The entry requirements and duration of the courses were also discussed and finalised, allowing lecturers to be identified and commissioned. Throughout proceedings, the flexibility of the course was held as the key criteria for the success of this new training programme.

As a result of careful management the postgraduate programmes were established by the HZS in close collaboration with Ghent University (UGent), Flanders Hydraulics, and partners from the maritime industry. The official launch of the 'Institute for Hydrography' within the HZS took place in March 2012.

\section{Programme}

The postgraduate programmes in hydrography were established in full accordance with the IHO Standards of Competence S-5: a category B programme for hydrographic surveyors and a category A programme for chief hydrographic surveyors. Both programmes consist of a two year training course, during which the HZS provides a solid theoretical framework complemented by practical and hands-on experience. 


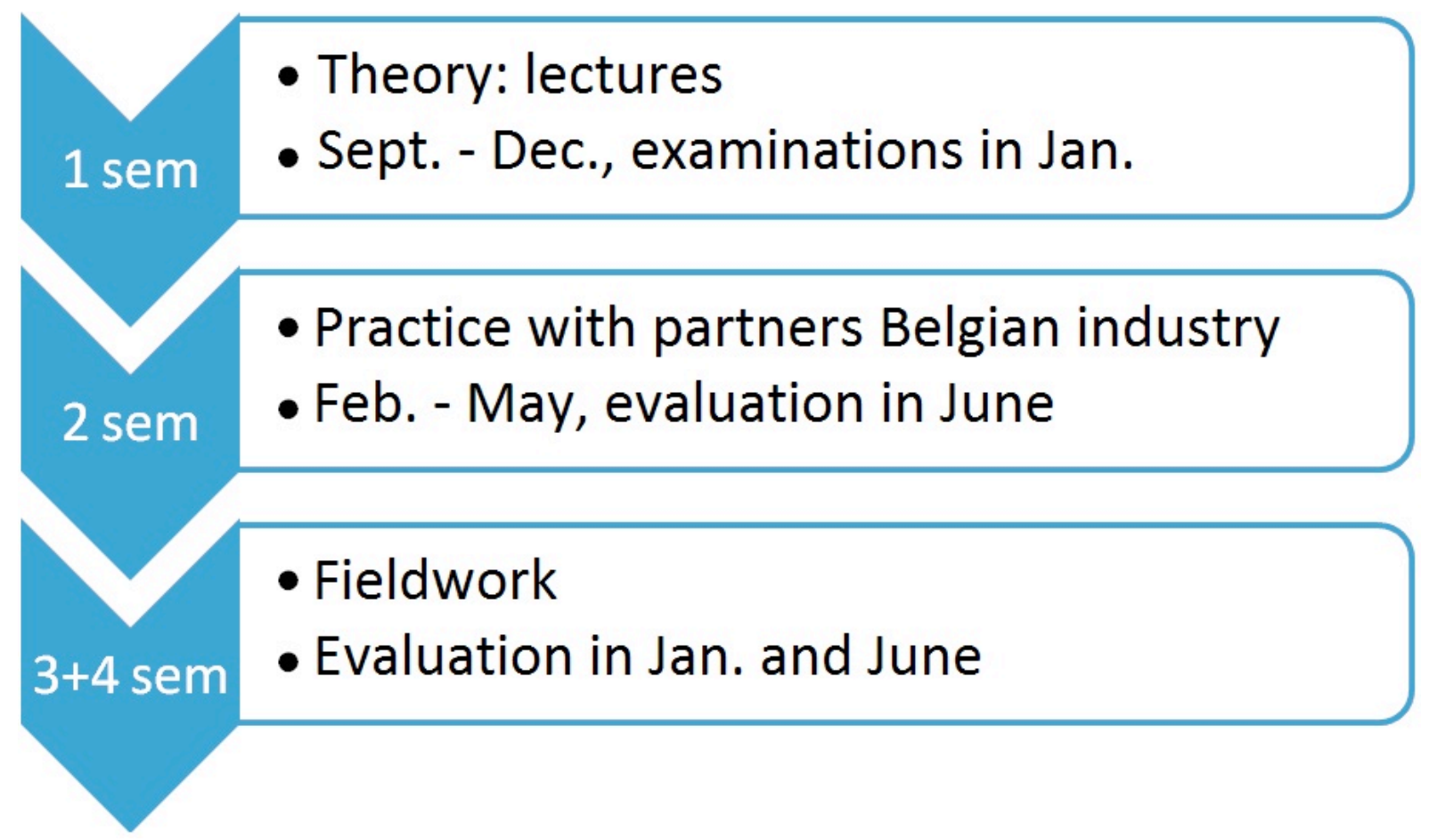

The timetables of the two, 2 year postgraduate programmes in hydrography run along similar lines. The first semester consists of 14 weeks of theory courses followed by examinations in January. This theory is then put into practice during a semester of practical projects, workshops, seminars and visits during which the students are rotated between different organizations, both industry practitioners and training establishments.

This approach provides the students with the opportunity to put their theoretical framework to good use in a practical environment. After successfully finishing this year of the programme, students are awarded a declaration.

The second year focuses on fieldwork at a company or institute, from amongst the partner organizations, to further develop the student's practical skills. During this year students experience real work as a hydrographer and prepare themselves thoroughly for their future careers.

After completion the student receives a category B or category A certificate depending on the programme they have been following.

\section{Quality and certification}

The Antwerp Maritime Academy is certified ISO 9001:2008 ${ }^{5}$. All activities of the Institute for Hydrography are incorporated into the Maritime Academy's quality system. As such, the school vouches for the high quality and excellence of its students, including hydrography postgraduates.

\footnotetext{
${ }^{5}$ ISO 9001 are a set of standardized requirements for a system of quality control employed by a firm or institution. More info on www.iso.org.
} 
A crucial element that grants accreditation and lends validity to a programme and certification such as this one is its acknowledgement by an institution of note, respected in the field. The HZS is in the process of acquiring acknowledgement by the International Hydrographic Organization (IHO) in Monaco, the authority in the field of hydrographic survey. This vital recognition will allow the programme to fully develop its reputation through excellent training, and to be at the forefront of development in the industry.

To continuously monitor the quality of the programme, an interactive correspondence with students and industry has been made an integral part of the programme. This results in a constant upgrading of the course and practical training, keeping all aspects of the programme fully up to date and on the leading edge of industry methods and thinking. For this purpose a steering council has been established within the Institute to ensure quality and innovation. The steering council is responsible for decision-making, oversight, monitoring and follow-up of the programmes.

Furthermore all courses are delivered by lecturers expert in their fields. The cooperation between the different partners allows specific knowledge and skills to be taught by those individuals best qualified to do so; leaders in their fields. The collaboration between the HZS and UGent results in an immediate concentration of collective knowledge and experience, which enables it to become one of the leading institutes of hydrography globally.

\section{Compatibility and Flexibility}

Candidates for the postgraduate programme cat. B are required to present a Bachelor's degree. There is no field of study specified so any Bachelor can be admitted. Candidates have to prove their knowledge of Mathematics and Physics, as well as sufficient English proficiency. The knowledge of basic sciences is essential as science is the basis of most courses and this minimum of scientific accomplishment should be established the beginning of the course.

Participants with relevant competences may be eligible for exemptions for certain modules. Based on documentary proof, the extensive application portfolio and personal interviews, a selection committee decides on exemptions for each candidate on an individual basis.

The programme structure allows the students great flexibility. Because of the modular system, the theoretical courses take place during the first semester of the first programme year. The second, third and fourth semester consists of fieldwork, during which the students engage in a specialized placement in the industry as trainees.

STCW educational decrees enable already active hydrographers to take up a flexible and individual curriculum. The candidate can choose to extend the programme courses over a period of maximum five years, thus allowing part-time work at one's own pace. This serves to ensure as seamless as possible an integration between existing in-house training arrangements and a more institution based approach.

\section{HYDROGRAPHY AT HZS}

The HZS as an educational institution focuses on the future with a scientific and innovative approach. Its aim is to provide outstanding programmes that answer to both the institute's 
standards and the international IHO standards of competence. Establishing a course in hydrography and meeting the demands of both the industry as well as the professional-tobe, was therefore a logical step. In addition to freeing up industry training resources and streamlining the process of becoming a hydrography professional, the benefits of centralised, concentrated yet easily accessible expertise are not to be underestimated.

Only a few institutes in Europe offer English language programmes in hydrography. With English as the course language, we are able to accommodate students from all over the world. With this, the Antwerp Maritime Academy underlines another element of its mission: international purveyance of education.

Continuous quality control and upholding high standards is a priority. The HZS pays extra attention to partnerships to safeguard the excellence of its training programmes. With a team of experts from academic and industry backgrounds, supported by specialized equipment, students receive a solid theoretical framework. The negotiated training opportunities enable students to practice their learnt skills in a professional environment, ensuring graduates are in the best possible position to thrive as hydrographers from the start of their careers.

Students can create an individual curriculum and study relevant subjects at a time most convenient and sensible for them in relation to their individual studies. Students may be eligible for exemptions from particular modules when they have previous knowledge or experience in a field. To ensure an open, international approach and increase accessibility, all courses are taught in English. This flexibility puts the programmes in an exceptional position to cater for students and active hydrographers alike.

\section{PROSPECTS}

The delivery of certified and capable hydrographers is the principle aim of these educational programmes. For a field that is in constant need of qualified people, in a country lacking any hydrographic training, the creation of the postgraduate programmes is a direct solution to the problems of this demand.

During the start-up of both programmes, its workings are closely monitored to evaluate and improve processes. The partnership with other educational facilities and interested parties within the maritime sector will ensure constant feedback and keep the training relevant at all times. At the same time the documentation needed for IHO accreditation will be finalized in order to validate the certificates issued by the HZS.

In the coming years the HZS envisions that the hydrography programmes will be promoted amongst students, interested people and people that are already active in the field. Academically, the postgraduate programmes would evolve towards a more standard academic structure to become more embedded and accepted as a field of study.

In the long run, the programmes aim to contribute to hydrographic institutions, the participating industry and the international nautical community as a whole. By employing high standards, the HZS aspires to deliver competent professionals, help build on the quality of education and make sea and subsea activities better and safer. 


\section{CONCLUSION}

Hydrography is an important field that should not be neglected by academic institutions, which through close links with industry are uniquely placed to drive forward expertise in this field. The demand for certified hydrographers calls for a programme that can provide this highly qualified personnel trained for the specific and demanding task at hand.

In just two years Belgium has gone from an optional introductory master course to a fullfledged programme with the collaboration of higher education institutes, governmental bodies and the industry itself. The quality, flexibility and international allure of this course provides present and future candidates from any background with an attractive set of skills and prospects.

The aim of the HZS is to equip their students with the necessary knowledge and abilities to become competent and confident hydrographic surveyors. Extensive practice and fieldwork combined with an approved theoretical framework will enable graduates to successfully pursue their professional careers in the hydrographic field.

\section{REFERENCES}

Bijlsma, Rodrigue. "Hydrografie. Het in kaart brengen van de Belgische hydrografische sector, de Europese IHO gecertificeerde opleidingen en Het Institute For Hydrography." Ma diss., Antwerp Maritime Academy, 2012.

Bijlsma, Rodrigue. "Hydrografie." Ba diss., Antwerp Maritime Academy, 2011.

Claeys, Annelies. "Rapport hydrografieonderzoek." Ma diss., Ghent University, 2009.

International Hydrographic Organization. Standards of competence for Hydrographic Surveyors S-5. Monaco: The Hydrographic Bureau, 2011. Accessed May 30, 2012. http://www.iho.int/iho_pubs/standard/S-5_Ed_11.0.1_06May2011_Standards-Hydro.pdf.

International Organization for Standardization. ISO 9000 essentials. Accessed June 6, 2012. http://www.iso.org/iso/iso_9000_essentials.

\section{CONTACT DETAILS}

Micha LIBERT

Antwerp Maritime Academy

Noordkasteel Oost 6

B-2030 Antwerpen

BELGIUM

Tel.: +32 32056481

Fax.: +3232250639

Email: micha.libert@hzs.be

Web site: www.hzs.be/hydrography

Linkedln account: http://be.linkedin.com/pub/micha-libert/46/b46/32 